\title{
EFFECT OF MONETARY POLICY ON ECONOMIC GROWTH IN NIGERIA IN THE POST STRUCTURAL ADJUSTMENT PROGRAMME
}

\author{
Kelechi Johnmary Ani \\ Alex Ekwueme Federal University, Nigeria \\ E-mail: kelechi.ani@funai.edu.ng \\ Chigozie Onu \\ Nnamdi Azikiwe University Awka, Nigeria \\ E-mail: asiano.jc@gmail.com \\ Submission: $11 / 4 / 2020$ \\ Revision: $12 / 15 / 2020$ \\ Accept: 1/5/2021
}

\section{ABSTRACT}

The study investigated the effect of monetary policy on economic growth during post structural adjustment programmer in Nigeria. It used the expo-facto design. Secondary data for the period of 1985-2015 were utilized. The data were extracted from the Central Bank of Nigeria (CBN) Statistical Bulletin and the National Bureau of Statistics (NBS). The linear regression with the application of Ordinary least Squares (OLS) technique was employed to estimate the parameters of the model numerically. Finding revealed that broad money supply had a positive and significant effect on economic growth in Nigeria during post structural adjustment programmer from 1986-2015. Interest rate had a negative and significant effect on economic growth in Nigeria during the same period and inflation rate had a positive and insignificant effect on economic growth in Nigeria at the same time. The study recommended that Central Bank of Nigeria should facilitate the emergence of market based interest rate that would attract both domestic and foreign investments, as well as create jobs, and promote nonoil export, while reviving industries that are currently operational, far below installed capacity. In order to strengthen the financial sector, the Central Bank has to encourage the introduction of more financial instruments that are flexible enough to meet the risk preferences and sophistication of operators in the financial sector. 
INDEPENDENT JOURNAL OF MANAGEMENT \& PRODUCTION (IJM\&P)

http://www.ijmp.jor.br

v. 12, n. 8, November-December 2021

ISSN: 2236-269X

DOI: 10.14807/ijmp.v12i8.1483

Keywords: Monetary policy, Economic growth, Structural Adjustment Program, Nigeria

\section{INTRODUCTION}

Monetary policy is a technique of economic management that aims to bring about sustainable economic growth and development. Monetary policy has been the pursuit of nations in their quest to transform their national economies. The formal articulation of how money affects economic aggregates dates back to the time of Adams Smith and was later championed by the monetary economists. Since the expositions of the role of monetary policy in influencing macroeconomic objectives like economic growth, price stability, equilibrium in balance of payments and host of other objectives; monetary authorities are saddled the responsibility of using monetary policy to grow their economies.

In Nigeria, monetary policy has been used since the Central Bank of Nigeria was saddled with the responsibility of formulating and implementing monetary policy. That mandate was coded in the Central Bank Act of 1958. It gave the bank the right to influence the Nigerian national monetary policy and issues. This role has facilitated the emergence of active money market where treasury bills, a financial instrument used for open market operations and raising debt for government has grown in volume and value, thereby becoming a prominent earning asset for investors and source of balancing liquidity in the market. There have been various regimes of monetary policy in Nigeria. Sometimes, monetary policy is tight and at other times it is loose and is mostly used to stabilize prices.

The economic environment that guided monetary policy before 1986 was characterised by the dominance of the oil sector, the expanding role of the public sector in the economy and over- dependence on the external sector. Thus, in order to maintain price stability and a healthy balance of payments position; monetary management is vital. It manipulates the use of direct monetary instruments such as credit ceilings, selective credit controls, administered interest and exchange rates, as well as the prescription of cash reserve requirements and special deposits to attain national economic interest. The use of market-based instruments was not feasible at that point because of the underdeveloped nature of the financial markets and the deliberate restraint on interest rates.

Scholars have revealed that before 1986, direct monetary control was used to achieve price stability in Nigeria but emphasis shifted to market mechanisms after the 1986 market liberalization (Ufoeze et al. 2018; Onwuteaka, Okoye \& Molokwu, 2019). The most popular instrument of monetary policy was the issuance of credit rationing guidelines, which primarily 
INDEPENDENT JOURNAL OF MANAGEMENT \& PRODUCTION (IJM\&P)

http://www.ijmp.jor.br

v. 12, n. 8, November-December 2021

ISSN: 2236-269X

DOI: 10.14807/ijmp.v12i8.1483

set the rates of change for the components and aggregate commercial bank loans and advances to the private sector.

The sectoral allocation of bank credit in CBN guidelines was to stimulate the productive sectors and thereby stem inflationary pressures. The fixing of interest rates at relatively low levels was done mainly to promote investment and growth. Occasionally, special deposits were imposed to reduce the number of free reserves and credit-creating capacity of the banks. Minimum cash ratios were stipulated for the banks in the mid-1970s on the basis of their total deposit liabilities, but since such cash ratios were usually lower than those voluntarily maintained by the banks, they proved less effective as a restraint on their credit operations.

From the mid-1970s, it became increasingly difficult to achieve the aims of monetary policy. Generally, monetary aggregates, government fiscal deficit, GDP growth rate, inflation rate and the balance of payments position moved in undesirable directions. Compliance by banks with credit guidelines was less than satisfactory. The major sources of the problem in monetary management were the nature of the monetary control framework, the interest rate regime and the non-harmonization of fiscal and monetary policies.

The monetary control framework, which relied heavily on credit ceilings and selective credit controls, increasingly failed to achieve the set monetary targets as their implementation became less effective with time. The rigidly controlled interest rate regime, especially the low levels of the various rates, encouraged monetary expansion without promoting the rapid growth of the money and capital markets. The low-interest rates on government debt instruments did not sufficiently attract private sector savers, and since the CBN was required by law to absorb the unsubscribed portion of government debt instruments, large amounts of high-powered money were usually injected into the economy.

In the oil boom era, the rapid monetization of foreign exchange earnings resulted in large increases in government expenditure which substantially contributed to monetary instability. In the early 1980s, oil receipts were not adequate to meet increasing levels of demands, and since expenditures were not rationalised, the government resorted to borrowing from the Central Bank to finance huge deficits, which had adverse implications for monetary management (CBN, 2012). The failure of monetary policy rules before 1986 to achieve the expected and desired results led to the policy shift from regulation to deregulation.

The Structural Adjustment Programme (SAP) was adopted in July 1986 against the crash in the international oil market and the resultant deteriorating economic conditions in the country. It was designed to achieve fiscal balance and balance of payments viability by altering and restructuring the production and consumption patterns of the economy, eliminating price 
INDEPENDENT JOURNAL OF MANAGEMENT \& PRODUCTION (IJM\&P)

http://www.ijmp.jor.br

v. 12, n. 8, November-December 2021

ISSN: 2236-269X

DOI: 10.14807/ijmp.v12i8.1483

distortions, reducing the heavy dependence on crude oil exports and consumer goods imports, as well as enhancing the non-oil export base and achieving sustainable growth.

Other aims were to rationalise the role of the public sector and accelerate the growth potentials of the private sector. The main strategies of the programme were the deregulation of external trade and payments arrangements, the adoption of a market-determined exchange rate for the Naira. They also adopted substantial reduction in price and administrative controls and became more reliance on market forces as a major determinant of economic activity.

The objectives of monetary policy since 1986 became the stimulation of output and employment, as well as the promotion of domestic and external stability. In line with the general philosophy of economic management under SAP, monetary policy was aimed at inducing the emergence of a market-oriented financial system for effective mobilisation of financial savings and efficient resource allocation. The main instrument of the market-based framework is the open market operations. This is complemented by reserve requirements and discount window operations.

In order to improve macroeconomic stability, efforts were directed at the management of excess liquidity; thus a number of measures were introduced to reduce liquidity in the system. These include the reduction in the maximum ceiling on credit growth allowed for banks and the recall of the special deposits requirements against outstanding external payment arrears to CBN from banks. There was also the abolition of the use of foreign guarantees/currency deposits as collaterals for naira loans and the withdrawal of public sector deposits from banks to the CBN. In August 1990, the use of stabilisation securities for purposes of reducing the bulging size of excess liquidity in banks was re-introduced. Commercial banks' cash reserve requirements were increased in 1989, 1990, 1992, 1996 and 1999.

The Nigerian economy has also witnessed times of expansion and contraction but evidently, the reported growth has not been a sustainable one as there is evidence of growing unemployment, high interest, persistent rise in price, weakening of naira and severe poverty among the populace. Could the period of growth be attributed to appropriate monetary policy? And could the periods of recession be blamed on factors other than monetary policy ineffectiveness? What measures are to be considered if monetary policy would be effective in bringing about sustainable economic growth? In relation to the above question, the study investigated the effect of monetary policy on economic growth during post structural adjustment programme in Nigeria. 
DOI: 10.14807/ijmp.v12i8.1483

\section{LITERATURE REVIEW}

\subsection{Monetary Policy as a Tool for Economic Growth}

Monetary policy has thus been known to be a vital instrument that a country can use to facilitate economic growth, maintain domestic price and exchange rate stability as a critical condition for the achievement of a sustainable economic growth and external viability (Adegbite \& Alabi, 2013). Monetary policy may be inflationary or deflationary depending upon the economic condition of the country. Contractionary policy is enforced to squeeze down the money supply to curb inflation and expansionary policy is to stimulate economic activity to combat unemployment in recession (Shane Hall, 2010).

According to Anyanwu (2003), countries seeking for sustainable economic growth after a period of macroeconomic imbalances must first get stabilized. The quest for sustainable growth in Nigeria in the early 1980's, led to the introduction of Structural Adjustment Programme (SAP), in response to the emergence and persistence of unstable macroeconomic instability. The Structural Adjustment Programme monetary policy was aimed at moderating inflation, increasing domestic savings, allocating resources efficiently, improving capital inflow and local production and employment, enhancing external reserves and stabilizing the naira exchange rate. According to Anyanwu (2003), countries seeking for sustainable economic growth after a period of macroeconomic imbalances must first get stabilized. In Nigeria, monetary policy effectively implemented is an important tool for stable economic growth.

\subsection{Monetary Policy and Economic growth}

Folawewo and Osinubi (2006) presented monetary policy as a combination of measures designed to regulate the value, supply and cost of money in an economy, in consonance with the expected level of economic activity. For most economies, the objectives of monetary policy include price stability, maintenance of a balance of payments equilibrium, promotion of employment, output growth, and sustainable development. These objectives are necessary for the attainment of internal and external balance, and the promotion of long-run economic growth.

Evidence in the Nigerian economy has shown that since the 1980's some relationship exist between the stock of money and economic growth. Over the years, Nigeria has been controlling her economy through variation in her stock of money. Consequent upon the effect of the collapse of oil price in 1981 and the Balance of Payment (B.O.P) deficit experienced during this period, various methods of stabilisation ranging from fiscal to monetary policies 
were used. Interest rates were fixed, and these were said to be beneficial to big borrower farmers (Ojo, 1989).

The monetary policy is essential to achieve desired objectives which traditionally include promoting economic growth, achieving full employment level, reduction in the level of inflation, maintenance of a healthy balance of payment, sustenance of growth in the economy, increase in industrialisation and economic stability. The supplementary objective of monetary policy includes the smoothing of the business cycle, preventing financial crisis and stabilization of long-term interest rates. Stabilizing the real exchange rate have been identified recently as part of supplementary objectives of monetary policy because of global financial crisis that often engulfed major developed and emerging economies in the world (Mishra \& Pradhan, 2008).

\subsection{Money Supply}

The supply of money is a stock at a particular point in time, though it conveys the idea of a flow over time. The concept, supply of money is synonymous with such terms as 'money stock' and quantity of money'. The supply of money at any moment is the total amount of money in the economy. There are three alternative views regarding the definitions or measures of money supply. The most common view is associated with the traditional and Keynesian thinking which stresses the medium of exchange function of money.

The second definition is broader and is associated with the modern quantity theorists headed by Friedman. According to him, money supply is literally the number of dollars people are carrying around in their pockets. Thus, this definition includes M1 plus time and deposits within commercial banks. This wider definition is characterised as M2.

\subsection{Exchange Rate}

Foreign Exchange refers to as the financial transaction where currency value of one country is traded for another country's currency. The whole process gets done by a network of various financial institutions like bank, investors and government. Conceptually, an exchange rate connotes the price of one currency in terms of another. Nationally, in the Nigeria situation, it is the units of naira needed to purchase one unit of another country's currency (e. g. the United States dollar). That is the value of the naira in terms of the dollar or pounds sterling in the case of the United States (U.S.) or United Kingdom (U.K) respectively. Our major discussion is based on the Nigerian currency. 
DOI: $10.14807 /$ ijmp.v12i8.1483

The evolution of the foreign exchange market in Nigeria up to its present state was influenced by a number of factors such as the changing pattern of international trade, institutional changes in the economy and structural shifts in production. Before the establishment of the Central Bank of Nigeria (CBN) in 1958 and the enactment of the Exchange Control Act of 1962, foreign exchange was earned by the private sector and held in balances abroad by commercial banks which acted as agents for local exporters.

During this period, agricultural exports contributed the bulk of foreign exchange receipts. The fact that the Nigerian pound was tied to the British pound sterling at par, with easy convertibility, delayed the development of an active foreign exchange market. However, with the establishment of the CBN and the subsequent centralization of foreign exchange authority on the Central Bank, the need to develop a local-foreign exchange market became paramount.

\subsection{Gross Domestic Product}

GDP is the Gross Domestic Product, which is the total money value of final goods and services within an economy for a given fiscal year. The rate at which Gross Domestic Product grows is known as economic growth. Economic growth is enabled by increases in productivity, which lowers the inputs (labour, capital, material, energy, etc.) for a given amount of output. It should be noted that lowered costs increase demand for goods and services.

The equation used to calculate GDP is as follows:

GDP = Consumption + Government Expenditures + Investment + Exports - Imports

The components used to calculate GDP include:

Consumption:

1. Durable goods(items expected to last more than three years)

2. Nondurable goods (food)

3. Services

Government Expenditures:

1. Defense

2. Roads

3. Schools 
DOI: 10.14807/ijmp.v12i8.1483

Investment Spending:

1. Nonresidential (spending on plants and equipment), Residential (single-family and multi-family homes)

2. Business inventories

Net exports:

1. Exports are added to GDP

2. Imports are deducted from GDP

The GDP report also includes information regarding inflation:

1. The implicit price deflator measures changes in prices and spending patterns.

2. The fixed-weight price deflator measures price changes for a fixed basket of over 5,000 goods and services.

GDP is calculated both in current dollars and in constant dollars. Current Dollar GDP involves calculating economic activity in present-day dollars. This, however, makes time period comparisons difficult due to the effects of inflation. By comparison, Constant Dollar GDP factor out the impact of inflation and allows for easy comparisons by converting the value of the dollar in other time periods to present-day dollars.

\section{THEORETICAL REVIEW}

This study is based on Keynesian IS-LM framework with a Philips curve superimposed on it to determine inflation. The mechanism is such that changes in monetary policy (usually specified as exogenous shifts in monetary aggregates) affect the money supply, which changes interest rate to balance the demand with supply (Chuku, 2009). The changes in interest rates then affect investment and consumption, which latter causes changes in output and price. Modifying the classical quantity theory of money, the Keynesians believe that money supply, through its transmission mechanism, has indirect effect on the real GDP.

Monetarists while agreeing to Keynes that in the short run economy does not operate at full employment, therefore expansionary monetary policy may work positively in the long-run, they support classists that rising money supply will increase inflation only. Therefore, they suggest that the policy must accommodate increase in real GDP without changing price level (LanLord, 2008). 
INDEPENDENT JOURNAL OF MANAGEMENT \& PRODUCTION (IJM\&P)

http://www.ijmp.jor.br

v. 12, n. 8, November-December 2021

ISSN : 2236-269X

DOI: $10.14807 /$ ijmp.v12i8.1483

Most of the modern economists are of the view that long-run growth depends upon enhancement of productivity, especially if an appropriate monetary policy is supplemented by the external environment with suitable liquidity, interest rate, robust demand, and soft assistance from the World Bank (Russell, 2010).

Monetarists strongly believe that monetary policy exact greater impact on economic activity as unanticipated change in the stock of money affects output and growth, i.e. the stock of money must increase unexpectedly for the Central Bank to promote economic growth. In fact, they are of opinion that an increase in government spending would crowd out private sector and such can outweigh any short-term benefits of an expansionary fiscal policy (Adefeso \& Mobolaji, 2010).

\section{EMPIRICAL REVIEW}

Adegbite and Alabi (2013) examined the impact of monetary policy on economic growth in Nigeria, using secondary data from Central Bank of Nigeria Statistical Bulletin covering the period of 1970 to 2010. Multiple regressions were employed to analyze data on variables like money supplies; inflation, exchange rate, interest rate and gross domestic product, which were all found to have significant effects on the economics growth with the Adjusted R2 of 58\%.

Following the outcome of that study, it was, therefore, concluded that exchange rate stability has played a key role in keeping inflation low for most of the transition period, and that the range of monetary policy instruments available to the authorities has widened in recent years and this has been associated with more stable and predictable changes in money supply and the price level. Similarly, Ayodeji and Oluwole (2018) used multi-variable regression analysis to study the impact of monetary policy on economic growth in Nigeria.

However, Chuku (2009) carried out a controlled experiment using a Structural Vector Autoregression (SVAR) model to trace the effects of monetary policy shocks on output and prices in Nigeria. The study assumed that the Central Bank cannot observe unexpected changes in output and prices within the same period. This places a recursive restriction on the disturbances of the SVAR. Three alternative policy instruments i.e. broad money (M2), minimum rediscount rate (MRR) and the real effective exchange rate (REER) were used.

Overall, the study found evidence that monetary policy innovations carried out on the quantity-based nominal anchor (M2) has modest effects on output and prices with a very fast speed of adjustment. While, innovations on the price-based nominal anchors (MRR and REER) have neutral and fleeting effects on output. The study concluded that the manipulation of the 
INDEPENDENT JOURNAL OF MANAGEMENT \& PRODUCTION (IJM\&P)

http://www.ijmp.jor.br

v. 12, n. 8, November-December 2021

ISSN: $2236-269 X$

DOI: 10.14807/ijmp.v12i8.1483

quantity of money (M2) in the economy is the most influential instrument for monetary policy implementation.

Gul, Mughal and Rahim (2012) reviewed how the decisions of monetary authorities influence the macro variables such as GDP, money supply, interest rates, exchange rates and inflation. The method of least squares was used in the data analysis. The sample was taken from 1995-2010 and included observations were 187. Result shows that interest rate had negative and significant impact on output. Tight monetary policy in term of increase interest rate had significant negative impact on output. Money supply has strongly positive impact on output, hence, positive inflation and output is negatively correlated, exchange rate also had negative impact on output which shows from the values.

Hsing and Hsieh (2004) assessed the impact of monetary policy on economic performance of China. They used VAR model to generate impulse function and variance decomposition to determine the effect of shocks on economic performance. Their policy variables are real M2, interest rate, exchange rate and their target variables are real GDP and inflation. They found that the GDP and inflation responds negatively to standard deviation shock in interest rate, and that local currency appreciated (Chinese Yuan) thereby concluding that interest rate is the most important variable affecting GDP.

Again, Hsing and Hsieh (2009) determined the impact of monetary policy on real output in China and its provinces. They found that the coastal provinces responded more to shocks than Inland provinces. Their findings show that interest rate is the most significant variable affecting their target variable GDP. This result corroborates with their earlier study on interest rates as the most significant variable explaining the changes in GDP.

The Error Correction Mechanism and Cointegration technique were adopted by Adefeso, and Mobolaji (2010) to estimate the relative effectiveness of fiscal and monetary policy on economic growth in Nigeria using annual data from 1970-2007. The empirical result showed that the effect of monetary policy is stronger than fiscal policy and the exclusion of the degree of openness did not make weak this conclusion.

Spithilat and Sun (2017) examined the impact of monetary policy on the economic development of Lao using annual time series data from 1989 to 2016. Amassoma et al. (2011) examined the effect of monetary policy on macroeconomic variables in Nigeria for the period 1986 to 2009 by adopting a simplified Ordinary Least Squared technique. They found that that monetary policy had a significant effect on exchange rate and money supply while monetary policy was observed to have an insignificant influence on price instability. 
DOI: $10.14807 /$ ijmp.v12i8.1483

Onyeiwu (2012) examines the impact of monetary policy on the Nigerian economy using the Ordinary Least Squares Method (OLS) to analyse data between 1981 and 2008. The result of the analysis shows that monetary policy presented by money supply had a positive impact on GDP growth and Balance of Payment had a negative impact on the rate of inflation. Khan and Senhadji (2001) conducted a study using penal data for 140 developing and industrialised countries for the period of 1960-98. They suggested a threshold level beyond which the inflation had a negative effect on economic growth. Threshold levels were 1-3 percent and 7-11 percent for industrial and developing countries respectively.

\section{RESEARCH METHODOLOGY}

The study employed the expo-facto design. The study proposes to estimate the models numerically using time series secondary data for the period of 1985-2015. The data were primarily extracted from the Central Bank of Nigeria (CBN) Statistical Bulletin and the National Bureau of Statistics (NBS). The linear regression with the application of Ordinary least Squares (OLS) technique was employed to estimate the parameters of the model numerically.

\subsection{Model Specification}

To investigate the effect of monetary policy on economic growth during post structural adjustment programme in Nigeria, the following model below were estimated using sets of data mainly on monetary policy (broad money supply, inflation rate and interest rate) and economic growth (real gross domestic product).

Rgdp $=\mathrm{f}\left(\mathrm{M}_{2}\right.$, Ir, inf $)$

Further specification

$$
\operatorname{Rgdp}=\beta_{0}+\beta_{1} m 2+\beta_{2} \mathrm{ir}+\beta_{3} \inf +U_{t}
$$

Where,

$$
\begin{array}{ll}
\text { Rgdp } & =\text { Real Gross Domestic Product } \\
\mathrm{M}_{2} & =\text { broad money supply } \\
\mathrm{IR} & =\text { Interest rate } \\
\mathrm{INF} & =\text { Inflation } \\
\beta_{0} & =\text { Equation constant }
\end{array}
$$


ISSN: $2236-269 X$

DOI: 10.14807/ijmp.v12i8.1483

$\mathrm{b}_{1}$ - $_{3}=$ Coefficient of explanatory variables

$\mathrm{U}_{\mathrm{t}} \quad=$ Error term

\subsection{Analysis of data and interpretations}

Table1: Descriptive statistics

\begin{tabular}{|l|c|c|c|c|}
\hline & RGDP & M2 & IR & INF \\
\hline Mean & 8959469. & 4571494. & 20.10000 & 19.77617 \\
\hline Median & 2755202. & 1073890. & 19.08500 & 13.22500 \\
\hline Maximum & 40544100 & 20029831 & 29.80000 & 72.80000 \\
\hline Minimum & 69147.00 & 23806.40 & 10.50000 & 5.400000 \\
\hline Std. Dev. & 12206499 & 6406532. & 4.278302 & 17.73932 \\
\hline Skewness & 1.383129 & 1.245977 & 0.290239 & 1.648974 \\
\hline Kurtosis & 3.657017 & 3.064826 & 2.925795 & 4.590907 \\
\hline & & & & \\
\hline Jarque-Bera & 10.10481 & 7.767543 & 0.428075 & 16.75931 \\
\hline Probability & 0.006394 & 0.020573 & 0.807318 & 0.000229 \\
\hline \multicolumn{2}{|c|}{} & & & \\
\hline Sum & $2.69 \mathrm{E}+08$ & $1.37 \mathrm{E}+08$ & 603.0000 & 593.2850 \\
\hline Sum Sq. Dev. & $4.32 \mathrm{E}+15$ & $1.19 \mathrm{E}+15$ & 530.8122 & 9125.825 \\
\hline \multicolumn{2}{|c|}{30} & 30 & 30 & 30 \\
\hline Observations & & &
\end{tabular}

The mean values are presented in the Table. For instance, mean value for inflation is 19.77617, while that for money supply is 4571494, interest rate $=20.10000$ and Real gross domestic product $=8959469$. The Jargue-Bera statistics indicates that most of the data series have normal distribution. This is indicated by the probability value of JB statistics which for most series are significantly different from zero at $1 \%$ levels of significance.

Table 2: Unit root test

\begin{tabular}{|l|l|l|l|l|}
\hline Variables & $\begin{array}{l}\text { Test } \\
\text { Statistics }\end{array}$ & $\begin{array}{l}5 \% \text { Critical } \\
\text { Value }\end{array}$ & Level & S/NS \\
\hline INF & -0.238 & 0.815 & $1(1)$ & S \\
\hline M2 & -3.291 & 0.0029 & $1(1)$ & S \\
\hline IR & 0.3853 & 0.977 & $1(1)$ & S \\
\hline RGDP & -3.188 & 0.0048 & $1(0)$ & S \\
\hline
\end{tabular}

To test for stationarity, the Augmented Dickey Fuller (ADF) Unit Root Test is used and $5 \%$ critical value is selected. The results in Table 2 show that inflation, interest rate and broad money supply M2 were not stationary at level but were stationary at 1st difference.

Table 3: Causality test

Pairwise Granger Causality Tests

Date: 10/03/17 Time: 07:13

Sample: 19862015

Lags: 2

\begin{tabular}{lccc}
\hline \hline Null Hypothesis: & Obs & F-Statistic & Prob. \\
\hline \hline M2 does not Granger Cause RGDP & 28 & 0.10895 & 0.8972 \\
RGDP does not Granger Cause M2 & & 4.08437 & 0.0303 \\
\hline \hline
\end{tabular}


INDEPENDENT JOURNAL OF MANAGEMENT \& PRODUCTION (IJM\&P)

http://www.ijmp.jor.br

v. 12, n. 8, November-December 2021

ISSN: 2236-269X

DOI: 10.14807/ijmp.v12i8.1483

\begin{tabular}{|c|c|c|c|}
\hline $\begin{array}{l}\text { IR does not Granger Cause RGDP } \\
\text { RGDP does not Granger Cause IR }\end{array}$ & 28 & $\begin{array}{l}1.12079 \\
0.65213\end{array}$ & $\begin{array}{l}0.3432 \\
0.5303\end{array}$ \\
\hline $\begin{array}{l}\text { INF does not Granger Cause RGDP } \\
\text { RGDP does not Granger Cause INF }\end{array}$ & 28 & $\begin{array}{l}0.21209 \\
0.94812\end{array}$ & $\begin{array}{l}0.8105 \\
0.4021\end{array}$ \\
\hline $\begin{array}{l}\text { IR does not Granger Cause M2 } \\
\text { M2 does not Granger Cause IR }\end{array}$ & 28 & $\begin{array}{l}1.03411 \\
0.97490\end{array}$ & $\begin{array}{l}0.3715 \\
0.3923\end{array}$ \\
\hline $\begin{array}{l}\text { INF does not Granger Cause M2 } \\
\text { M2 does not Granger Cause INF }\end{array}$ & 28 & $\begin{array}{l}0.67749 \\
0.96746\end{array}$ & $\begin{array}{l}0.5177 \\
0.3950\end{array}$ \\
\hline $\begin{array}{l}\text { INF does not Granger Cause IR } \\
\text { IR does not Granger Cause INF }\end{array}$ & 28 & $\begin{array}{l}2.88183 \\
0.43829\end{array}$ & $\begin{array}{l}0.0764 \\
0.6504\end{array}$ \\
\hline
\end{tabular}

Granger causality tests are conducted to determine whether causality exists between broad money supply and real gross domestic product, interest rate and gross domestic product and inflation rate and gross domestic product. This indicates that no causality runs between the variables.

\section{RESULT AND INTERPRETATIONS}

Table 4: showed the regression result of the impact of monetary policy on economic growth

in Nigeria during the post structural adjustment programme (1986-2015)

\begin{tabular}{|c|c|c|c|c|}
\hline \multicolumn{3}{|c|}{ Dependent Variable: RGDP } & & \\
\hline \multicolumn{3}{|c|}{ Method: Least Squares } & & \\
\hline \multicolumn{5}{|c|}{ Date: 10/03/17 Time: 07:32 } \\
\hline \multicolumn{5}{|c|}{ Sample: 19862015} \\
\hline \multicolumn{5}{|c|}{ Included observations: 30} \\
\hline Variable & Coefficient & Std. Error & t-Statistic & Prob. \\
\hline $\mathrm{C}$ & 25640183 & 9266727. & 2.766908 & 0.0103 \\
\hline M2 & 1.116548 & 0.340541 & 3.278743 & 0.0030 \\
\hline IR & -1085061. & 489141.5 & -2.218297 & 0.0355 \\
\hline INF & 1250.279 & 119913.7 & 0.010426 & 0.9918 \\
\hline R-squared & 0.361023 & \multicolumn{2}{|c|}{ Mean dependent var } & 8959469. \\
\hline Adjusted R-squared & 0.287295 & \multicolumn{2}{|c|}{ S.D. dependent var } & 12206499 \\
\hline S.E. of regression & 10304953 & \multicolumn{2}{|c|}{ Akaike info criterion } & 35.25771 \\
\hline Sum squared resid & $2.76 \mathrm{E}+15$ & \multicolumn{2}{|c|}{ Schwarz criterion } & 35.44454 \\
\hline Log likelihood & -524.8657 & \multicolumn{2}{|c|}{ Hannan-Quinn criter. } & 35.31748 \\
\hline F-statistic & 4.896683 & \multicolumn{2}{|c|}{ Durbin-Watson stat } & 0.816045 \\
\hline Prob(F-statistic) & 0.007889 & & & \\
\hline & & & & \\
\hline
\end{tabular}

$\mathrm{RGDP}=25640183+1.116548 \mathrm{M} 2-1085061 \mathrm{IR}+1250.279 \mathrm{INF}$

The following regression line implies that 1 percent increase in broad money supply and inflation rate will result to change in real gross domestic product by 25640183 and interest rates, decrease by 1 percent, real gross domestic product will change by the same amount. 36 percent variations in the dependent were accounted by the independent variables. 
DOI: 10.14807/ijmp.v12i8.1483

Furthermore, the coefficient estimate of broad money supply is positive and its p- value is less than 0.05 at $5 \%$ confidence level. It means that broad money supply had a positive and significant effect on economic growth in Nigeria during post structural adjustment programme from 1986-2015. Interest rate had a negative and significant effect on economic growth in Nigeria during post structural adjustment programme from 1986-2015 and inflation rate had a positive and insignificant effect on economic growth in Nigeria during post structural adjustment programme from 1986-2015.

\section{CONCLUSION AND RECOMMENDATIONS}

The study analyzed the effect of monetary policy on economic growth in Nigeria during the post Structural Adjustment Programme (1986-2015). Broad money supply had a positive and significant effect on economic growth in Nigeria during post Structural Adjustment Programme from 1986-2015. Interest rate had a negative and significant effect on economic growth in Nigeria during post Structural Adjustment Programme from 1986-2015 and inflation rate had a positive and insignificant effect on economic growth in Nigeria during post Structural Adjustment Programme from 1986-2015. Thus, in Nigeria, monetary policy effectively implemented is an important tool for stable economic growth.

Finally, the study recommends that Central Bank of Nigeria should facilitate the emergence of market based interest rate that attract both domestic and foreign investments, create jobs, and promote non-oil export and revive industries that are currently operating far below installed capacity. In order to strengthen the financial sector, the Central Bank has to encourage the introduction of more financial instruments that are flexible enough to meet the risk preferences and sophistication of operators in the financial sector. Lastly, the broad money supply and inflation rate are positively related to gross domestic product. Therefore, active measures should be directed towards control of inflation rate during the post-SAP period.

\section{REFERENCES}

Adebiyi, M. A. (2006). Financial sector reforms and the transmission mechanism of monetary policy in Nigeria: A vector autoregression mechanism China Finance Research Network (CFRN).

Adefeso, H., \& Mobolaji, H. (2010). The fiscal- monetary policy and economic growth in Nigeria: Further empirical evidence. Pakistan Journal of Social Sciences, 7(2), 142

Adefeso, H. A., \& Mobolaji, H. I. (2010). The fiscal-monetary policy and economic growth in Nigeria: Further empirical evidence. Pakistan Journal of Social Sciences, 7(2), 137-142. DOI: 10.3923/pjssci.2010.137.142. 
Adegbite, T. A., \& Alabi, W. O. (2013). Monetary policy and economic growth: The Nigerian experience (1970-2010). Prime Journal of Business Administration and Management, 3(1), 822-833.

Ajayi, F. O., \& Atanda, A. A. (2012). Monetary Policy and Bank Performance in Nigeria: A Two-Step Cointegration Approach. African Journal of Scientific Research, 9(1), 461-476

Ajisafe, R. A., \& Folorunso, B. (2002). The relative effectiveness of fiscal and monetary policy in macroeconomic management in Nigeria. The African Economic and Business Review, 3(1), 23-40.

Amassoma, D., Nwosa, P. I., \& Olaiya, S. A. (2011). An appraisal of monetary policy and its effect on macroeconomic stabilisation in Nigeria. Journal of Emerging Trends in

Economics and Management Sciences, 2(3), 232-237.

Ayodeji, A., \& Oluwole, A. (2018). Impact of Monetary Policy on Economic Growth in Nigeria. Open Access Library Journal, 5(e4320), 13.

Batini, N. (2004). Achieving and maintaining price stability in Nigeria. IMF Working Paper WP/04/97, June.

Busari,D., Omoke, P., \& Adesoye, B. (2002). Monetary policy and macroeconomic stabilisation under Alternative exchange rate regime: evidence from Nigeria.

Chimobi, O. P., \& Uche, U. C. (2010). Money, price and output. A causality test for Nigeria. American Journal of Scientific Research, 8, 78-87.

Chuku, A. C. (2009). Measuring the effects of monetary policy innovations in Nigeria. Africa Journal of Accounting, Economics, Finance and Banking Research, 5(5).

Folawewo, A. O., \& Osinubi, T. S. (2006). Monetary policy and macroeconomic instability in Nigeria. A rational expectation approach. Journal of Social Sciences, 12(2), 93-100.

Gul, H., Mughal, K., \& Rahim, S. (2012). Linkage between monetary instruments and economic growth, Universal Journal of Management and Social Sciences, 2(5), 69-76.

Nnanna, (2002). Inflation Pressures and Continuous Fall in Foreign Exchange in Nigeria. A publication of Central Bank of Nigeria, 4, 34-49, CBN Press Limited, Nigeria Nnanna, (2003). Link Between Monetary and Fiscal Policy in Nigeria. A publication of University of Abuja, Economics Department, 6, 113-134, University of Abuja Press, Nigeria

Onyeiwu, C. (2012). Monetary policy and economic growth of Nigeria. Journal of Economics and Sustainable Development, 3(7), 62 -70.

Oyejide, (2002). Exchange Rate Volatility in Nigeria. A Journal of University of Ibadan, Faculty of Social Sciences, 18, 67- 94, University Press Ibadan.

Russell, M. (2010). Monetary policy and interest rates, Ezine articles. What is the monetary policy effect on GDP. Unemployment, inflation and interest rates.

Sanusi, (2001). Monetary Policy Expansion. a Central Bank of Nigeria publication, 171, 6479, CBN publication

Srithilat, K., \& Sun, G. (2017). The Impact of Monetary Policy on Economic Development: Evidence from Lao, PDR Global Journal of Human Social Science E Economics, 17(2), 816 
ISSN: 2236-269X

DOI: 10.14807/ijmp.v12i8.1483

Ufoeze, L. O., Odimgbe S. O., Ezeabalisi, V. N., \& Alajekwu, U. B. (2018). Effect of Monetary Policy on Economic Growth in Nigeria: An Empirical Investigation, Annals of Spiru Haret University, Issue 1 